\title{
Comparative Clay Analysis and Curation for Archaeological Pottery Studies
}

\section{Ann S. Cordell, Neill J. Wallis, and Gerald Kidder}

Ceramic ecology emphasizes the importance of environmental context and resource availability in the production of pottery (Arnold 1975, 1985; Kolb and Lackey 1988; Matson 1965; Rice 2015; Sillar 2000). Whereas material choices are largely shaped by culture, resource selection is also constrained by natural availability. Therefore, a comparative database of raw materials is essential to archaeological considerations of vessel production and provenance (Bishop and Blackman 2002).

Toward this end, natural clay deposits have long been studied by archaeologists as a way to understand spatial variation in chemistry and mineralogy, which is relevant to performance characteristics of pottery fabrics as well as useful as provenance markers (e.g., Jorge et al. 2013; Kelly et al. 2011; Michelaki et al. 2015; Neff and Bove 1999; Rice 2015; Stark et al. 2000). Although most comparative clay studies in archaeology are project specific and limited in scope, there are distinct benefits to studying clays on a large scale with consistent protocols. Unlike archaeological material culture that is the mainstay of museum collections, procedures and protocols for curating clay samples for archaeological research are not well documented.

\section{ABSTRACT}

We describe the curation and use of clay samples as part of the ceramic ecology program at the Florida Museum of Natural History's Ceramic Technology Laboratory (FLMNH-CTL). We outline the history of the comparative clay sample collection at the FLMNH-CTL and detail the standard operating procedure by which samples are processed, analyzed, and curated. We also provide examples of how the clay samples have been used in research projects as well as some of the challenges inherent to studies using such samples. Our collection of processed clays and associated thin sections, which is curated in perpetuity, represents a valuable resource for ongoing and future lab endeavors and is available to other researchers focusing on Florida and adjacent regions.

En este artículo describimos la conservación y el uso de muestras de alfarería como parte del programa de ecología cerámica del Laboratorio de Tecnología Cerámica del Museo de Historia Natural de Florida. Explicamos la historia de la colección de muestras de barro del laboratorio y el procedimiento operativo estándar para procesarlas, analizarlas y organizarlas. Describimos también ejemplos del uso de estas muestras en proyectos de investigación, así como algunos problemas inherentes en los estudios comparativos de arcilla. Nuestra colección comparativa de arcilla y secciones delgadas asociadas, que está curada de manera permanente, representa un recurso valioso para los esfuerzos en curso y a futuro del laboratorio, y está disponible para otros investigadores cuyo trabajo se enfoca en la Florida y las regiones adyacentes. 
This article outlines the ceramic ecology program at the Florida Museum of Natural History (FLMNH), which is the culmination of decades of work and brings together materials from many different independent projects to provide a robust comparative clay inventory in Florida and adjacent regions. We outline the history of the clay sample collection at FLMNH's Ceramic Technology Laboratory (FLMNH-CTL), established in 1977 by Prudence Rice, ${ }^{1}$ and detail the standard operating procedure by which samples are processed and curated. We offer this as a "how-to of best practices" for processing and curation. We also describe how the samples have been used in research projects and some of the challenges inherent to studies using comparative clay samples.

\section{BACKGROUND}

The FLMNH-CTL is equipped for basic paste characterization studies: binocular microscope for gross identification of temper or paste constituents, a petrographic microscope for precise mineral identification in thin section, a rock saw for cutting specimens for thin sectioning or for refiring, and an electric furnace for firing and refiring experiments.

The FLMNH-CTL also houses an extensive type collection of prehistoric and historic-period aboriginal pottery from Florida and the southeastern United States (view our website: http://www.flmnh.ufl.edu/ceramiclab/home/). We have also established a comparative "library" of pottery and clay sample thin sections, generated primarily from characterization studies conducted here at FLMNH-CTL. We currently house over 800 thin sections of pottery ${ }^{2}$ and 303 of curated fired clay samples, ${ }^{3}$ mostly from Florida.

Research conducted in the lab addresses research questions regarding chronology, provenance or manufacturing origins, processes of production, patterns of vessel use, culture change, and the development of sociopolitical and economic complexity in prehistoric Florida, the southeastern United States, and the Caribbean Basin. Collection and comparative analysis of clays from the vicinity of archaeological sites of interest, à la Frederick R. Matson's ceramic ecological approach (1965; Rice 2015:209-211) have been part of lab endeavors since its inception. Targeted collecting was directed toward assessing the "effective ceramic environment" (Rice 1987:314-315) of a given site area or region, at least in terms of availability and variability in clayey resources. An assemblage of collected sample clays may not actually have been used by prehistoric potters in question, but they may be considered to approximate the range of mineralogical and chemical variation of a given area or region of interest.

\section{COMPARATIVE CLAY SAMPLE COLLECTION AT FLMNH-CTL}

Over the years, we have accumulated more than 350 clay or clayey soil samples. Two hundred and fifty-one samples are from 40 Florida counties, representing 60 percent of Florida's 67 counties. In addition, we have 66 samples from Georgia, 21 from elsewhere in the southeastern United States, and 25 from other locales, mostly from the Caribbean and South America. This collection has been steadily augmented each year through the efforts of FLMNH staff as well as by unaffiliated Florida researchers, graduate students, and, occasionally, members of the general public. Many samples came through targeted collecting near specific sites or regions. Many others were encountered and collected during cultural resource management projects.

Our definition of "clay" follows that described by Rice: "a fine-grained earthy material that becomes plastic or malleable when moistened" (1987:36). Therefore, we consider comparative samples to be viable clays if there is evidence of plasticity, the property that allows a wetted clay to be shaped by pressure and to retain form when the pressure is relaxed. A soil sediment containing as little as 15 percent clay-sized particles may exhibit plasticity. By this criterion, potentially viable clay resources, in USDA (1951) Soil Conservation Service terms, include clay loam, sandy clay loam, silty clay loam, sandy clay, silty clay, and clay. Mucky and peaty sediments are also of interest owing to their apparent association with sponge spicules, a siliceous microfossil that is common to some types of Florida pottery (Borremans and Shaak 1986; Cordell 2004, 2007; Lollis et al. 2015; Wallis et al. 2014).

Collecting protocols are discussed in Quinn (2013) and Rice (1987, 2015). For targeted collecting, we consult USDA Soil Conservation Service maps and U.S. Geological Survey publications to locate clayey subsoils and deposits (e.g., Cordell 1984; Saffer 1979). The Florida soils maps and geological publications are available online, expediting targeted searches: http://www.nrcs.usda.gov/wps/portal/nrcs/detail/fl/soils/?cid= nrcs141p2_014982 and http://ufdc.ufl.edu/fgs. A searchable database has also been created from Florida soil survey data (http://soils.ifas.ufl.edu/flsoils/index.asp) and the actual Florida soil survey samples are stored on the University of Florida's (UF) campus. For us, field collecting may become unnecessary in some cases, as it may be possible to subsample from the UF soils archive for comparative study, although we have yet to take advantage of this resource.

Samples collected or sent to FLMNH-CTL are accompanied by a sample collection record (Table 1). This document describes the context of collection, form, thickness, extent of the deposits, and characteristics in situ. Ideally, sampling of different areas of a deposit is recommended in order to evaluate horizontal and/or vertical variation in physical properties (e.g., aplastics, primary colorants) (Quinn 2013:132; Rice 2015:254-255), but this has been attained in only a few cases (Cordell 1984; Saffer 1979). Rice recommends sampling a bucketful or about $5 \mathrm{~kg}$ of a deposit for experimentation, but most samples donated to our collection represent smaller quantities. The minimum volume required for the processing described below is $1.5 \mathrm{~kg}$ to $2 \mathrm{~kg}$, or enough to fill a quart-sized commercial plastic zipper bag or half of a gallon-sized zipper bag.

Incoming samples are assigned an FLMNH accession number and a clay sample number that denotes state and county of collection (e.g., "c8VO1" refers to the first sample accessioned from Volusia County, Florida). The "c" prefix has been added so that clay sample number designations are not mistaken for Florida archaeological site numbers. Clay samples from targeted 
TABLE 1. Example of Clay Sample Collection Record.

\begin{tabular}{l} 
CLAY SAMPLE COLLECTION RECORD \\
SAMPLE \#: c8VO1; FLMNH accession 2002-65 \\
DATE collected: November 3, 1998; COLLECTOR/RECORDER: Steve Koski \\
COLLECTION LOCATION: St. Johns River/Lake Monroe, Volusia County, Florida. Sandford, FL. quadrangle mp, midpoint of eastern half of \\
Section 16, Township 19S, Range 30E. \\
THICKNESS OF DEPOSIT: Indeterminate; recovered from $20 \mathrm{~cm}$ to $1.5 \mathrm{~m}$. \\
FORM AND EXTENT OF DEPOSIT: Extensive natural deposit measuring at least $100 \mathrm{~m}$ N/S by $50 \mathrm{~m}$ E/W. \\
HOW EXPOSED: Recovered from 4-inch bucket auger; several bucket auger samples dug in attempt to look for submerged component of \\
midden. Near shore, floodplain, and under l-4 bridge sampled. Most near lake and river location auger tests produced black clay. \\
Location of auger tests plotted on site map. \\
CHARACTERISTICS IN SITU: Thick, deep, extensive deposit of black, greasy clay. \\
MATERIAL OVERLYING: Variable depth of sand. \\
MATERIAL UNDERLYING: Indeterminate. \\
SURROUNDING NATURAL FEATURES: Lake Monroe, St. Johns River and floodplain, cypress swamp. \\
CULTURAL FEATURES: In the general vicinity of the Lake Monroe Outlet Midden (8VO53). \\
AMOUNT SAMPLED: 1/2 liter. \\
OTHER REMARKS: Clay collected during Phase 1 Cultural Resource Assessment Survey of I-4 PD\&E while bounding Lake Monroe Outlet \\
Midden for ACI on 1998. Collected from existing and proposed l-4 ROW. \\
\hline
\end{tabular}

Note: Form adapted from Rice (2015:255 [Table 14.2]; data adapted from Cordell and Koski 2003:118 [Table 2]).

studies were processed to make test bars and analyze grain size, and clay briquettes were fired and thin sectioned to characterize the samples in terms of physical properties that could be compared to pottery. Until 2012, only those targeted samples, or about 20 percent of our collection, had been processed (e.g., Cordell 1984, 1992; Espenshade 1985; Mitchem 1986).

Since 2012, the FLMNH-CTL has made a concerted effort to process and thin section the backlog of comparative clay samples as part of an ongoing project to evaluate compositional and textural variability of clayey resources in Florida and adjacent regions of interest, with momentum from grant-funded pottery provenance projects. This effort has benefited from the able assistance of volunteers, one of whom is our coauthor (Kidder), a retired UF Soil Sciences professor. ${ }^{4}$ As of this writing, we have completed processing of more than 90 percent of our accessioned collection of Florida samples. What follows is our standard operating procedure (SOP) for sample processing. The methods are also appropriate for processing of cached clays recovered archaeologically. The Appendix provides a list of equipment and supplies that relate to our SOP.

\section{STANDARD OPERATING PROCEDURE FOR FLMNH-CTL CERAMIC ECOLOGICAL SAMPLE CLAY ANALYSIS}

The SOP for processing our sample clays is adapted from lab instruction provided by Rice as part of her UF Anthropology Seminar in Ceramic Analysis, ${ }^{5}$ which she learned from her mentor, Dr. Fred Matson. After an FLMNH accession number and clay sample number have been assigned, incoming field samples are fumigated, an FLMNH policy. ${ }^{6}$ A given sample clay (of sufficient quantity) is then divided into two portions. The first is made into test bars, which are cut into briquettes for firing. The second is for grain-size analysis in which a sample is wet-sieved through a graduated series of ASTM International approved sieves (see Appendix). Both steps are taken to assess the sample's plasticity, shrinkage, and firing behavior; particle size and proportion; and aplastic composition. The recommended minimum sample is generally more than sufficient for making two test bars and subsampling for grain-size analysis.

\section{Handling Characteristics, Plasticity, and Shrinkage}

In making test bars, samples are evaluated in terms of handling characteristics, plasticity, and shrinkage. In Rice's seminar, clay samples were dried, crushed, and sieved through a \#8 sieve (opening $2.36 \mathrm{~mm}$ ). ${ }^{7}$ This process provides some indication of how much time and effort is required to crush and render a sample fine enough for use in pottery making and has many examples in the ethnographic literature on pottery making (e.g., Rice 2015:133). At FLMNH-CTL, our mode of processing depends on whether the sample is dried or still damp and plastic. If a sample comes into the lab damp and plastic, or if it is damp and plastic at the time of processing, we form test bars directly from the plastic, unaltered sample with minimal processing, usually limited to the addition of a little water and brief kneading and wedging. Large, obvious aplastics such as pebbles, shells, or plant material may be picked out by hand during this process. This choice of method allows us to expedite the processing of our backlog of samples. It also provides insight into the kinds of problems a potter might encounter in working with the clay in its unaltered, natural state.

If still damp at the time of processing, a baseball-sized handful is sufficient for making two test bars. Otherwise, $200 \mathrm{~g}$ of a dried, crushed, sieved sample is needed to make two test bars. Our bulk crushing "apparatus" is a homemade stanchion (a concrete-filled coffee can with a 0.61-m long handle) and samples 


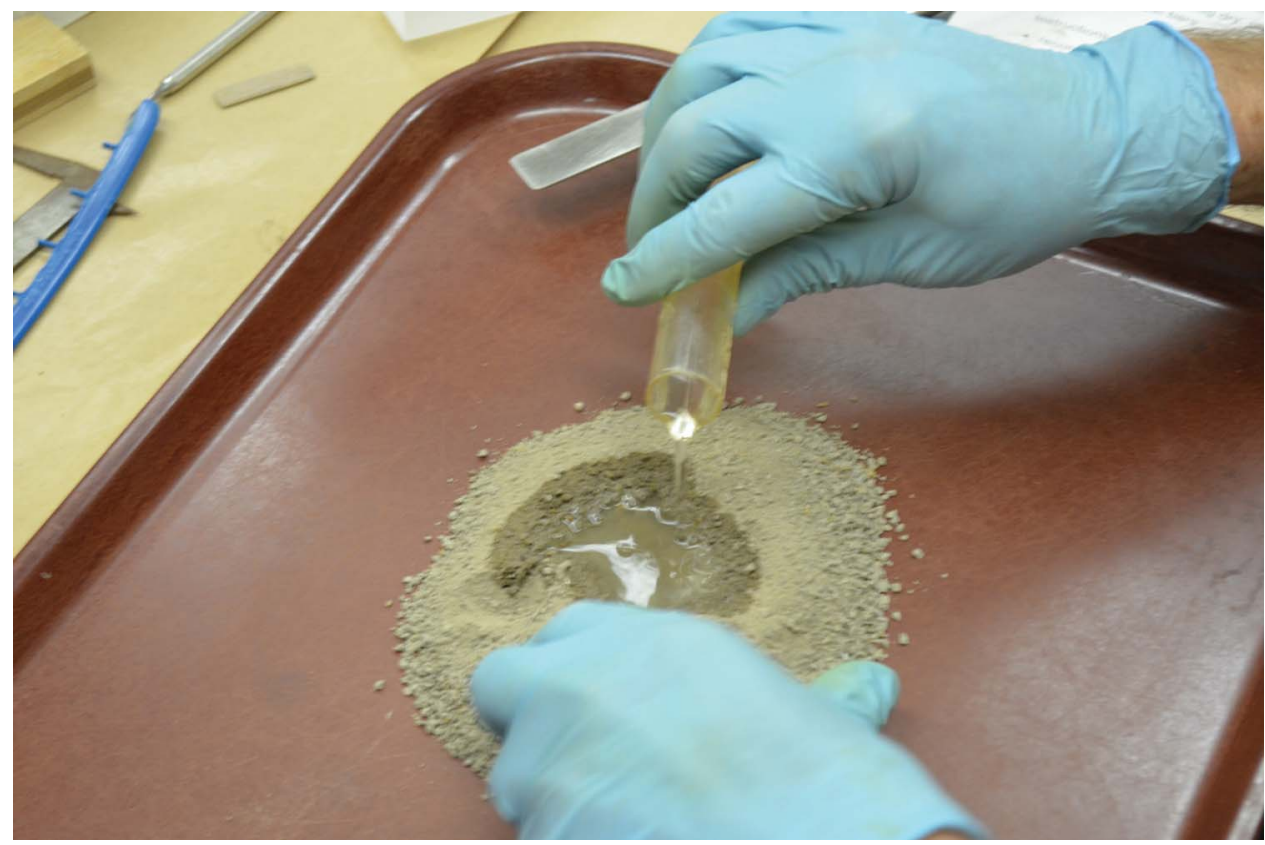

FIGURE 1. Water is added to depression in the pile of dry, crushed clay sample.

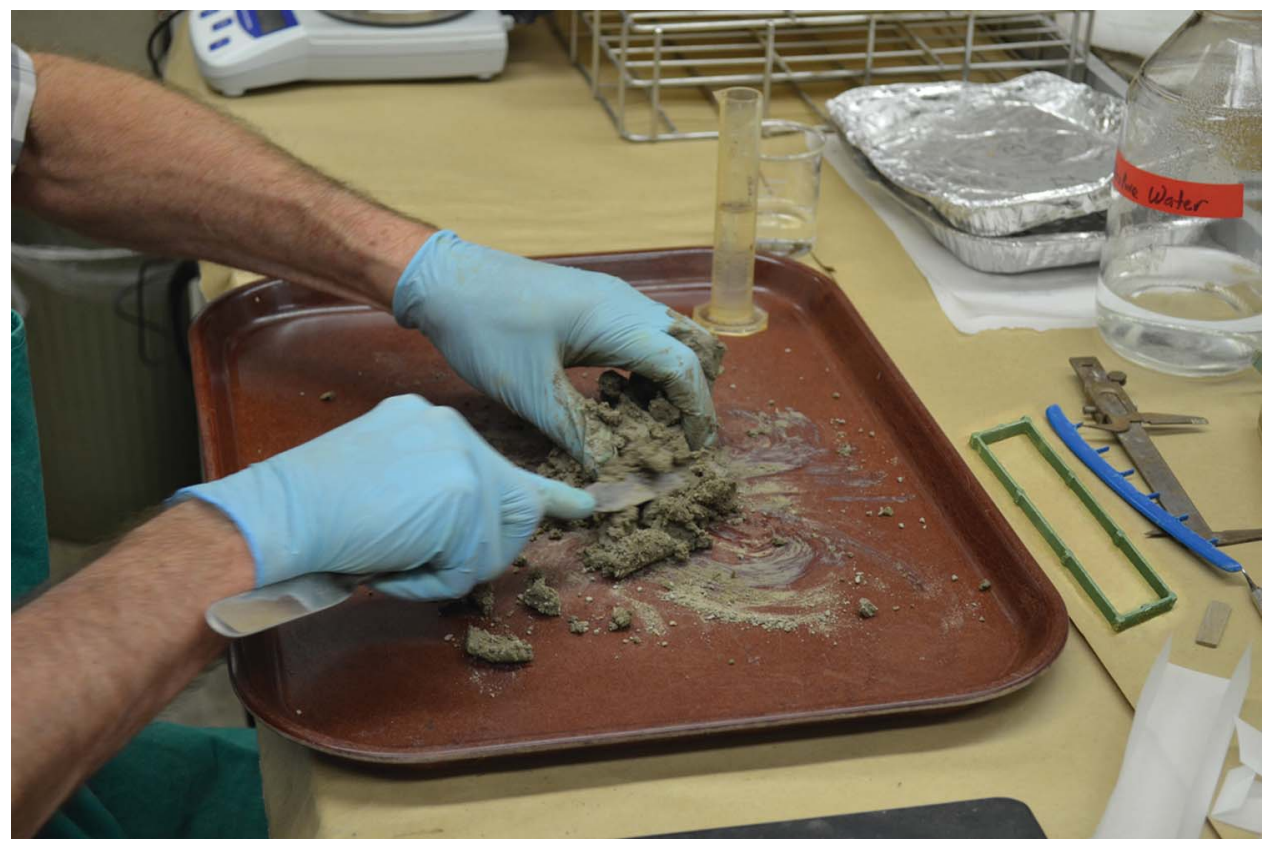

FIGURE 2. Working the clay and water into a plastic mass (test bar template also pictured).

are double-bagged in 4-mil zipper bags. Sealed processing contains dust generated during crushing/pounding, and reduces sample loss. A glass mortar and pestle is used for small samples.

Measured quantities of deionized water are added to the dried, crushed, sieved sample (Figure 1) until it is transformed into a workable, plastic mass (Figure 2). The amount of water added is recorded as a measure of Water of Plasticity, which refers to the amount of water required for clays to develop optimal plasticity
(Rice 2015:68-69). During this process, one can evaluate a sample's relative plasticity, texture, and working range. We wear nitrile gloves when working with samples to protect our hands from aplastics that may be irritants.

Test bars are formed after brief kneading and wedging. If the quantity of sample is insufficient for two test bars, then one test bar is made, with any leftover reserved for grain-size analysis. Test bars are made by pressing a short rope or log of plastic clay into 


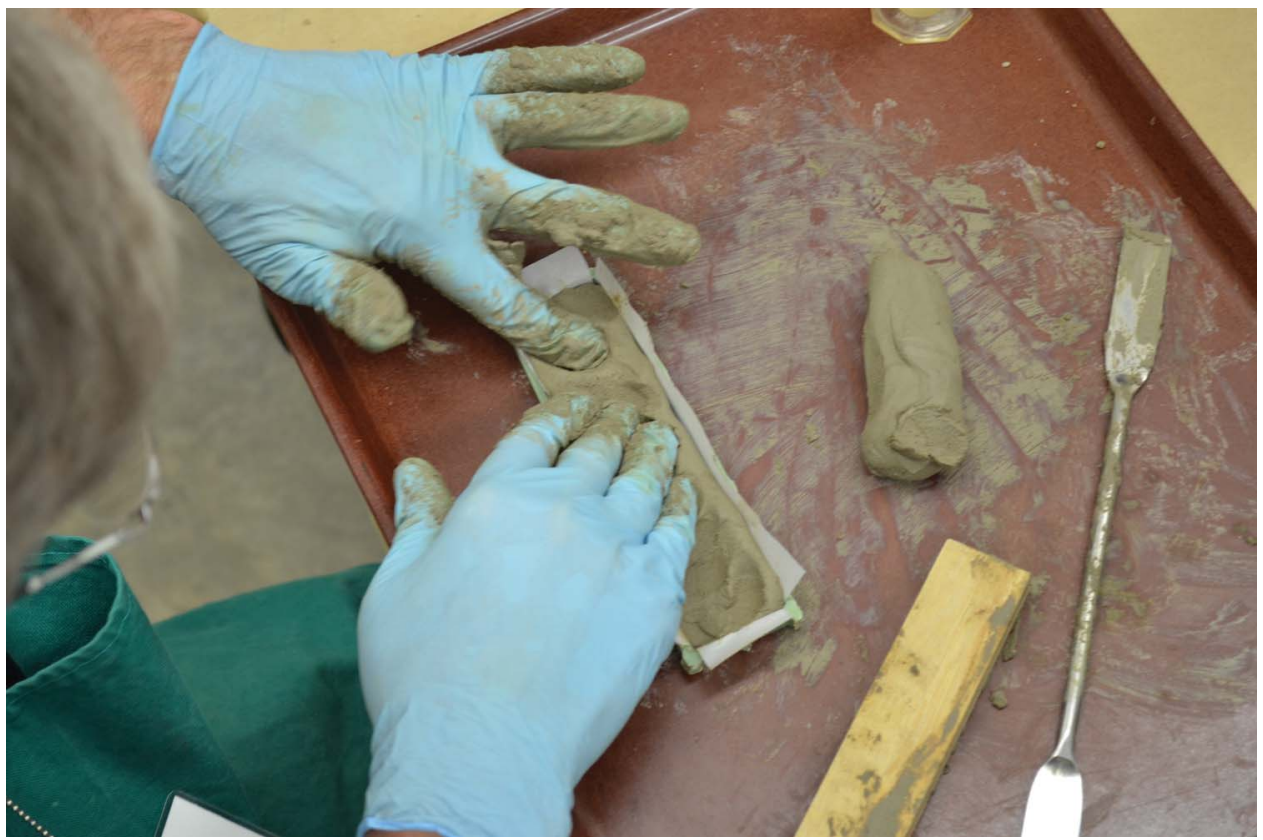

FIGURE 3. Pressing a "log" of plastic sample clay into a test bar template, lined with parchment paper (our template is recycled from an old army surplus industrial dishwasher rack; soon we will have a printable 3D file of this template to share with interested researchers).

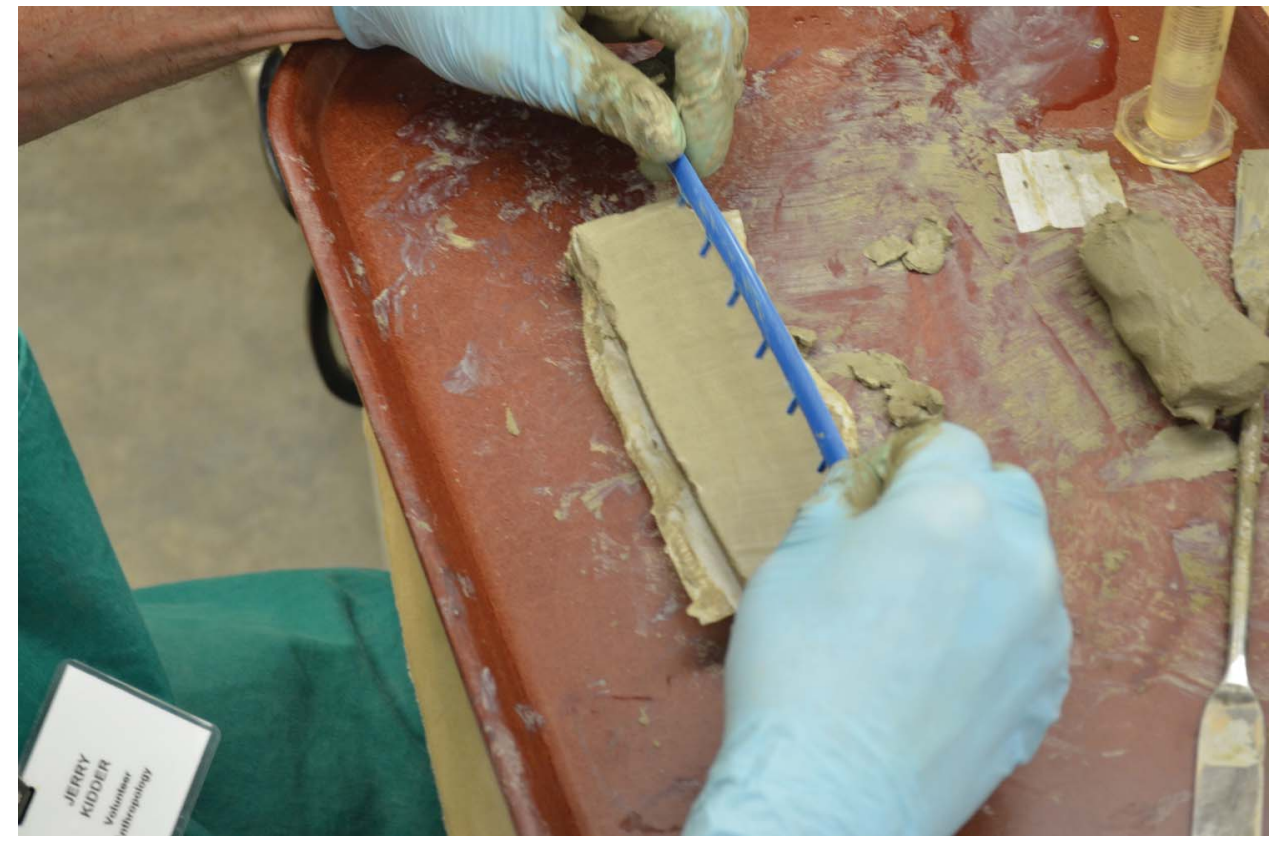

FIGURE 4. Marking scoring distances on sample clay test bar (with recycled hair comb tool). Take care that follow-up scoring lines are shallow (about $1 \mathrm{~mm}$ ) to avoid compromising the integrity of the bar (if too deep, the bar may separate along a scored line during drying).

a template (ours is made of plastic, $16.7 \times 4.3 \times 0.9 \mathrm{~cm}$; Figures 2 and 3). Lining the template with strips of parchment paper and using a wood block extruder make removing the bar from the template relatively easy. This is helpful with very plastic, sticky samples. The test bar surface is scored along five roughly equidistant segments (Figure 4) to make cutting dried bars into briquettes for firing easier. Any kind of pointed stylus or edged tool will work. We have recycled a hair comb for this purpose, with all but five equally spaced tines removed to mark the distances. Then we use an edged tool for scoring the lines. Each 


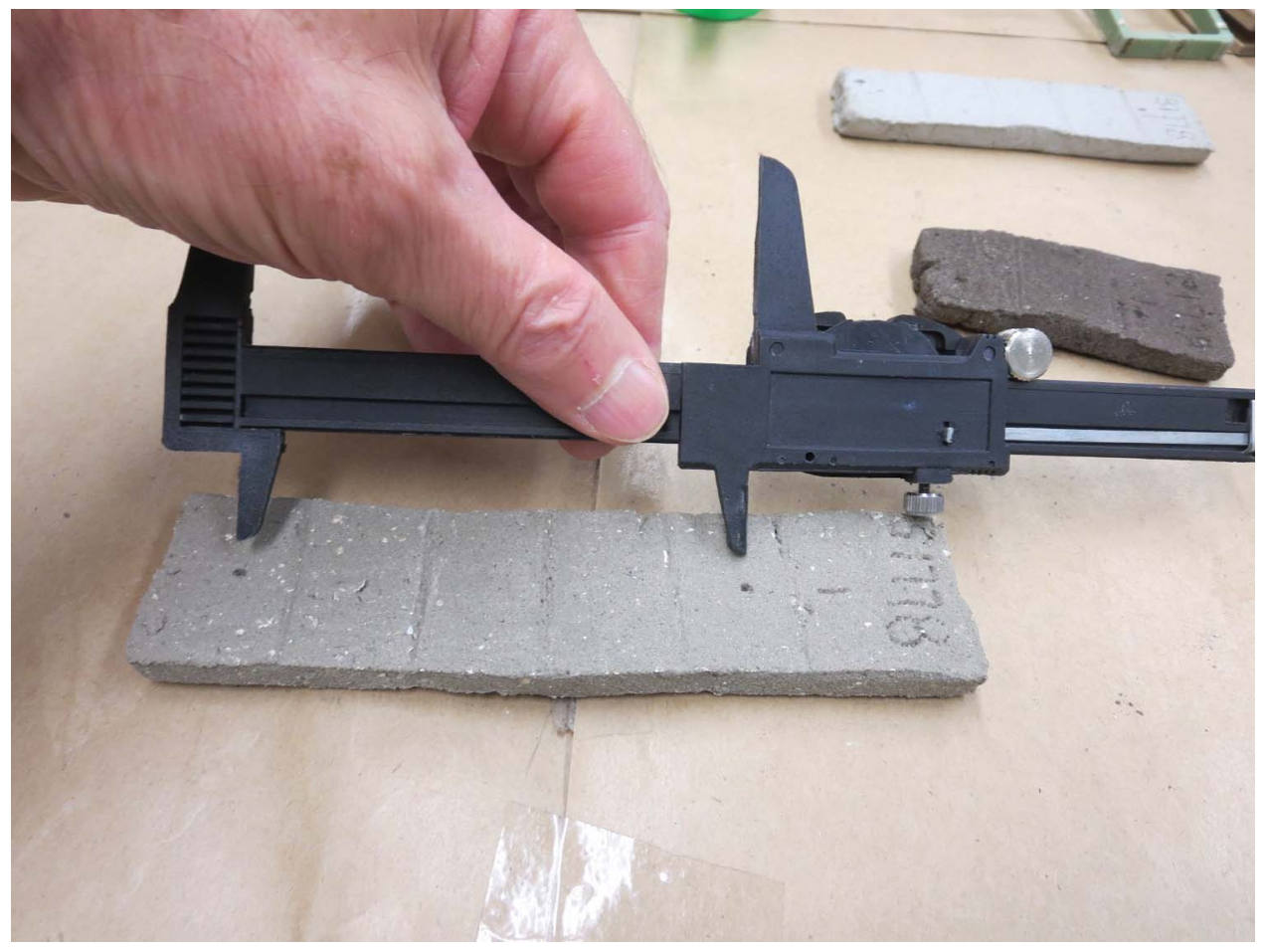

FIGURE 5. Marking bar with 10-cm distance with metric calipers for percent Linear Drying Shrinkage measurement.

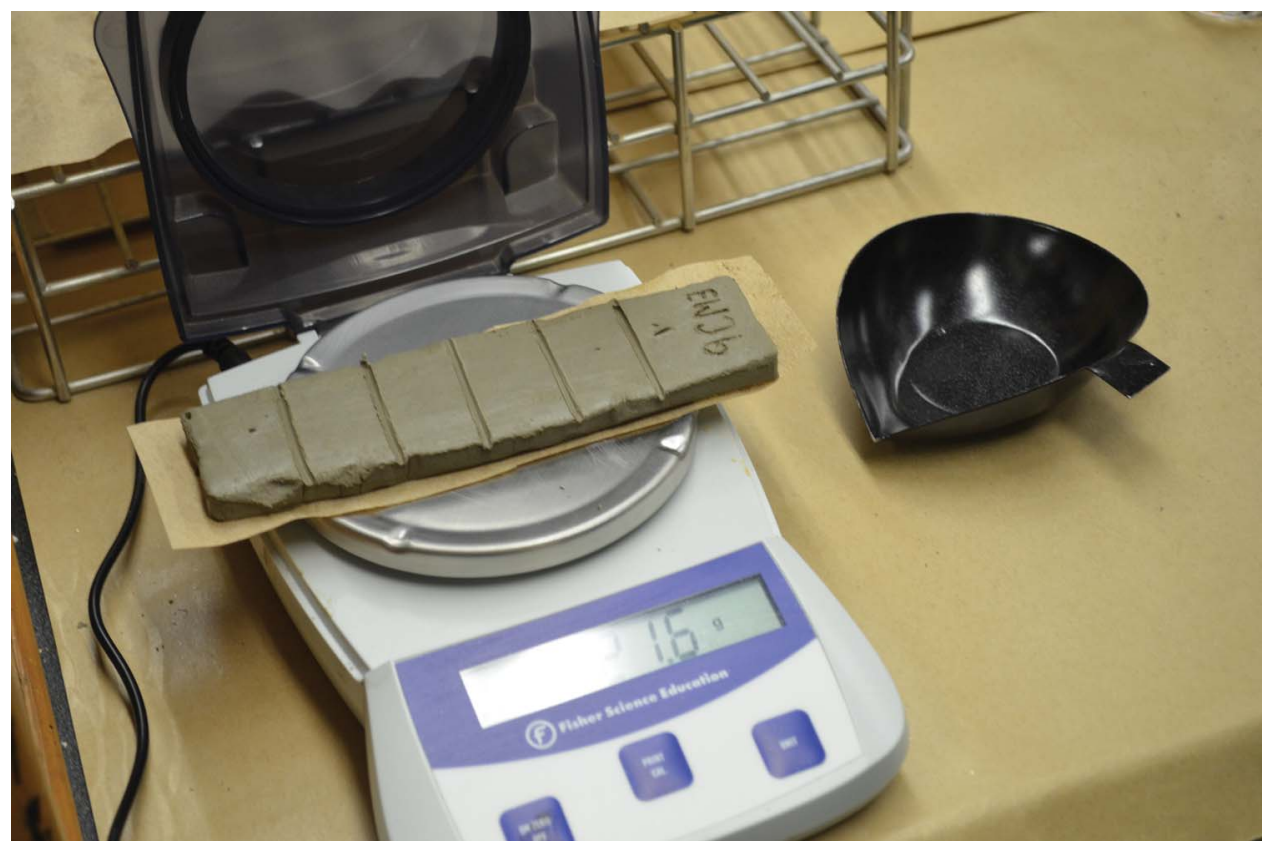

FIGURE 6. Weighing completed sample clay test bar for wet weight used in calculating percent Water of Plasticity.

completed test bar is labeled with a pointed stylus, carefully marked with 10-cm lengthwise distances (Figure 5) and weighed (Figure 6).

Test bars are next air-dried in the lab on an open rack and covered with paper towels for the first three days of drying, so that direct exposure to air is limited and the risk of warping and cracking is reduced (Rice 2015:89-94). After several days, any cracking or warping is noted. In terms of traditional pottery making, the addition of temper would likely be necessary to counteract excessive warping and shrinkage (Rice 2015:79; Rye 1981:31; Shepard 1976:25). 
TABLE 2. Example of Water of Plasticity and Linear Drying Shrinkage Data.

\begin{tabular}{|c|c|c|c|}
\hline \multicolumn{4}{|c|}{ Clay sample number: c8VO1, Lake Monroe clay sample } \\
\hline \multicolumn{4}{|c|}{ Amount of water added (if applicable): none; bars made from plastic, unaltered clay } \\
\hline \multicolumn{4}{|c|}{ Comments on plasticity: seems very fine and "fat" or "rich" with good working properties; no cracks formed when manipulated } \\
\hline \multicolumn{4}{|c|}{$\begin{array}{l}\text { Comments on warping/shrinkage: no noticeable cracking during drying, but bars became quite warped; the addition of temper would } \\
\text { be needed in pottery making }\end{array}$} \\
\hline WATER OF PLASTICITY & \multicolumn{3}{|c|}{$\% \mathrm{WP}=\frac{\text { wet test bar weight }}{\text { dry test bar weight }}$ dry test bar weight $\times 100$} \\
\hline $\begin{array}{l}\text { TEST } \\
\text { BAR }\end{array}$ & $\begin{array}{l}\text { Wet Test Bar Weight (g) } \\
\text { (date: } 2 / 15 / 2001)\end{array}$ & $\begin{array}{l}\text { Dry Test Bar Weight (g) } \\
\text { (date: } 7 / 11 / 2001)\end{array}$ & $\begin{array}{l}\text { Water Of } \\
\text { Plasticity (\%) }\end{array}$ \\
\hline I & 93.8 & 61.9 & 51.5 \\
\hline II & 95.8 & 63.9 & 49.9 \\
\hline MEAN \%WP & & & 50.9 \\
\hline LINEAR DRYING SHRINKAGE & \multicolumn{3}{|c|}{$\%$ LDS $=\frac{\text { length wet }- \text { length dry }}{\text { length wet }} \times 100$} \\
\hline $\begin{array}{l}\text { TEST } \\
\text { BAR }\end{array}$ & $\begin{array}{l}\text { Wet Length }(\mathrm{cm}) \\
\text { (date: } 2 / 15 / 2001)\end{array}$ & $\begin{array}{l}\text { Dry Length }(\mathrm{cm}) \\
\text { (date: } 7 / 11 / 2001)\end{array}$ & $\%$ LDS \\
\hline I & 10.00 & 8.94 & 10.6 \\
\hline ॥ & 10.00 & 8.93 & 10.7 \\
\hline MEAN \%LDS & & & 10.65 \\
\hline
\end{tabular}

Note: Adapted from Cordell and Koski 20003:118 (Table 2).

Test bars are further dried in a drying oven (temperature of $105^{\circ} \mathrm{C}$ ) for about one hour, and then allowed to cool to room temperature. Dried test bars are next re-weighed and marked distances re-measured. These steps provide data for another measure of Water of Plasticity and for a measure of Linear Drying Shrinkage (Rice 2015:68 [Box 3.1] and 93 [Box 5.1], respectively). Linear Drying Shrinkage is a measure of the loss of adsorbed or mechanically combined water during air-drying. An example of \%WP and \%LDS data is presented in Table 2.

\section{Firing Behavior}

After \%WP and \%LDS are recorded, the dried test bars are cut or broken into small briquettes (approximately $3 \mathrm{~cm} \times 2 \mathrm{~cm}$ in size) for firing. A hacksaw or hammer and chisel may be required in some cases, but scoring facilitates this process. In some cases, scored bars snap apart along score lines with minimal effort. Briquettes are then fired in an electric furnace to a series of increasing temperatures to record change in color and oxidation of primary colorants (organic materials and iron compounds) with temperature (Rice 2015:288-289). Five firing temperatures are used, ranging from $400^{\circ} \mathrm{C}$ to $800^{\circ} \mathrm{C}$ at intervals of $100^{\circ} \mathrm{C}$, and each temperature level is maintained for 30 minutes (soak or dwell period). The atmosphere is oxidizing and is not intended to replicate conditions of original pottery firings. The furnace temperature is initially set at $275^{\circ} \mathrm{C}$ and held for 10 minutes with the furnace door opened slightly to allow for escape of residual mechanically combined water as vapor. The furnace door is then shut completely after the 10-minute dwell, and the temperature is increased to the desired temperature. ${ }^{8}$ The kiln door is opened slightly again after completion of the firing. When firing briquettes of a given sample together, a briquette is pulled from the furnace with tongs after completion of each desired temperature (draw trials) and placed in the drying oven to cool slowly. In our initiative to process our backlog of samples, briquettes of many samples are fired together at one temperature at a time (Figures $7 \mathrm{a}$ and $7 \mathrm{~b}$ ). The total firing time for $800^{\circ} \mathrm{C}$ firing is approximately 85 minutes from start to finish. Total firing times for the $400^{\circ} \mathrm{C}$ through $700^{\circ} \mathrm{C}$ firings range from approximately 65 to 80 minutes, respectively.

Upon completion of firing, briquettes are broken for recording Munsell colors and the presence or absence of dark coring to note when constituent organics appear to be completely oxidized (Figure 8). An example of color data is presented in Table 3. The $800^{\circ} \mathrm{C}$ briquettes are often used in color comparisons with pottery that has been refired to $800^{\circ} \mathrm{C}$. Refiring the pottery is necessary to eliminate the effects of original firing conditions, thereby standardizing the basis for color comparisons between samples. This allows us to assess the relative iron content of clay samples and pottery as a way to infer gross clay resource differences (Beck 2006; Rice 2015:288-289; Shepard 1976:105). The $800^{\circ} \mathrm{C} / 30$-minute dwell firing represents conditions that likely exceeded those of the original firings of most prehistoric and early historic aboriginal pottery in Florida and the southeastern United States.

Fired briquettes are labeled with firing temperature and boxed or bagged for curation. Firing temperature is written directly on fired briquettes with archival pens or a pen and India ink. But it is usually necessary first to paint a swatch of clear coat lacquer on the briquette before labeling. Firing temperature and sample clay number are written on zipper bags for crumbly or disintegrated briquettes.

\section{Grain-Size Analysis}

This procedure obtains the particle size distribution of inclusions in a, and captured fractions can be used for mineral analysis (Rice 


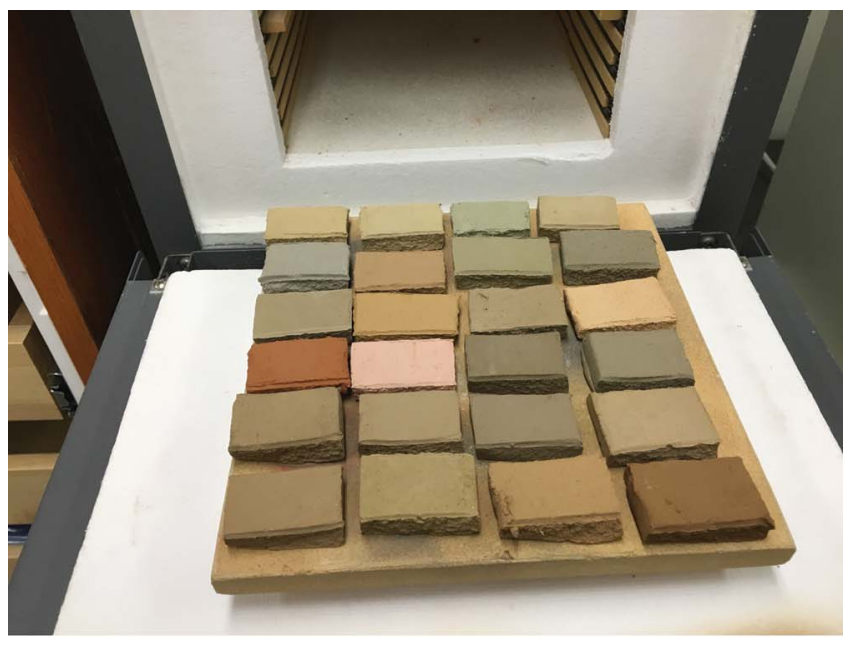

(a)

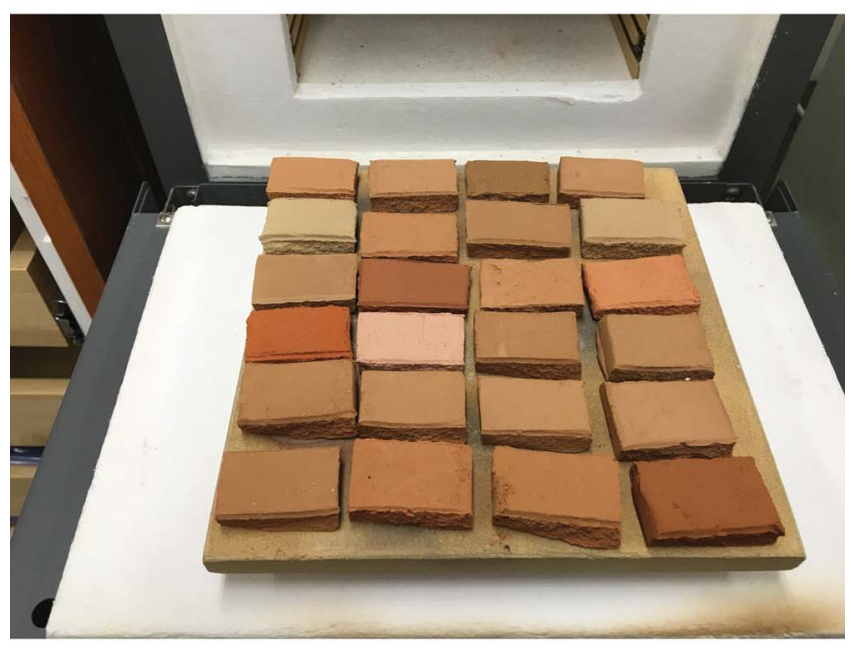

(b)

FIGURE 7. (a) Unfired briquettes from 24 different samples about to go into furnace; (b) the same briquettes after $800^{\circ} \mathrm{C}$ firing.
2015:76 [Box 4.1]). A 100-g portion (or less, depending on amount available) of dry or dried, uncrushed sample is reserved for grain-size analysis, without removing obvious impurities. A given sample is soaked in tap water for a few days before it is wetsieved through a graduated series of sieves. Sieves used in our lab bracket the range of Wentworth size categories (Wentworth 1922), ${ }^{9}$ listed in Table 4, which also presents an example of sieving results. By passing the sample through the finer sieves one at a time (instead of stacked) (Figure 9), we can conserve the amount of water required for the process. The volume of water used has been reduced from up to 34 liters (three 12-quart plastic basins) to no more than 4 liters (one or two 2-liter beakers) with this method. We place the sieves on a rack lined with paper toweling to air dry for about one week (Figure 10). When dry, the captured sediments are weighed and bagged for curation (in 4-mil zipper bags; Figure 11). The fine fraction, which passed through all sieves, is captured in a plastic basin or 2-liter glass beaker. After settling, most of the excess water is siphoned off. The fine fraction is then transferred to a smaller glass beaker, covered with aluminum foil, and dried thoroughly in the drying oven (Figure 12). The dry weight of the fine fraction is obtained by subtracting the beaker weight from the weight of beaker with the sediment. The fine fraction is then extracted and bagged for curation. Some clay samples may be very slow to settle (a deflocculated colloidal suspension of clay particles in water). In these cases, the suspension is siphoned from the settled fine fraction and flocculated with the addition of table salt (about one to three teaspoons). The flocculated portion is then combined with the rest of the fine fraction and dried, weighed, and bagged, as described above. The captured sieved sediments are then examined under a binocular microscope with 10-70X magnification and fiber optic illumination to record gross composition, which can be tested/corroborated by thin-section analysis and compared to pottery samples.

\section{Thin Sectioning and Other Initiatives}

In recent years, as funding has permitted, we have thin-sectioned processed samples for petrographic analysis. We use the $600^{\circ} \mathrm{C}$ briquette for thin sectioning, as it most closely approximates, or

TABLE 3. Example of Fired Color, Coring Data.

\begin{tabular}{|c|c|c|c|c|c|}
\hline \multirow{2}{*}{$\begin{array}{c}\text { Clay c8V01 } \\
\text { FIRING } \\
\text { TEMPERATURE }\end{array}$} & \multicolumn{2}{|c|}{ Core Color } & \multirow[b]{2}{*}{ Coring } & \multicolumn{2}{|c|}{ Surface Color } \\
\hline & $\begin{array}{l}\text { Munsell } \\
\text { color }\end{array}$ & $\begin{array}{l}\text { Munsell color } \\
\text { description }\end{array}$ & & $\begin{array}{l}\text { Munsell } \\
\text { color }\end{array}$ & $\begin{array}{l}\text { Munsell color } \\
\text { description }\end{array}$ \\
\hline dry, unfired briquette & $2.5 Y 2 / 0$ to $5 Y 2.5 / 1$ & black & & $2.5 Y 2 / 0$ to $5 Y 2.5 / 1$ & black \\
\hline $400^{\circ} \mathrm{C}$ briquette & $2.5 Y 2 / 0$ & black & heavy dark coring & 10YR 3/1 & very dark gray \\
\hline $500^{\circ} \mathrm{C}$ briquette & $2.5 Y 2 / 0$ & black & heavy dark coring & 10YR 4/1 & dark gray \\
\hline $600^{\circ} \mathrm{C}$ briquette & $2.5 Y 2 / 0$ & black & heavy dark coring & $2.5 Y R 7 / 4$ & pale yellow \\
\hline $700^{\circ} \mathrm{C}$ briquette & $2.5 Y 2 / 0$ & black & moderate dark coring & 10YR $7 / 3.5$ & very pale brown \\
\hline $800^{\circ} \mathrm{C}$ briquette & $2.5 Y 2 / 0$ & black & moderate dark coring & 10YR 7/4 & very pale brown \\
\hline
\end{tabular}

Note: Adapted from Cordell and Koski 2003:118 (Table 4). 


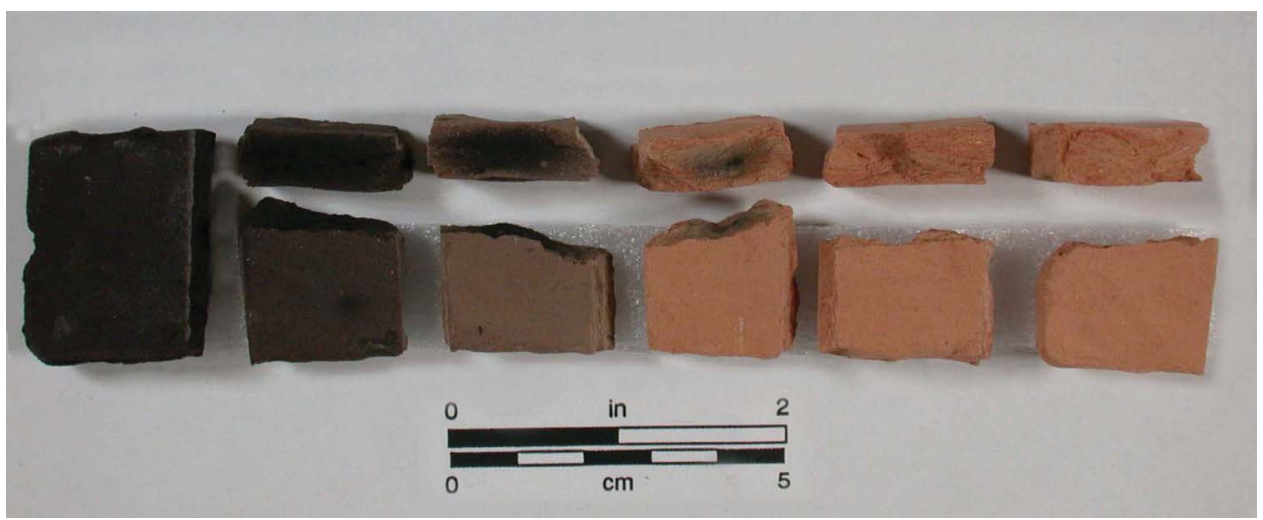

FIGURE 8. Fired briquettes are broken to record color change and coring loss.

TABLE 4. Example of Grain-Size Analysis Data.

\begin{tabular}{|c|c|c|c|}
\hline \multicolumn{4}{|c|}{ GRAIN-SIZE ANALYSIS: c8V01, Lake Monroe Clay } \\
\hline WENTWORTH SIZE & SIEVE \# (mm) & DRY WEIGHT, (\% wt) & PRINCIPAL CONSTITUENTS \\
\hline \multirow[t]{2}{*}{ GRANULE } & $\# 5(4.0 \mathrm{~mm})$ & $.08 \mathrm{~g}(.1 \%)$ & fossil bone, possibly turtle \\
\hline & $\# 10(2.0 \mathrm{~mm})$ & $.05 \mathrm{~g}(<.1 \%)$ & $\begin{array}{l}\text { equal parts plant debris, shell, quartz (subrounded and } \\
\text { subangular), and angular clay lumps }\end{array}$ \\
\hline VERY COARSE & \#18 (1.0 mm) & $.18 \mathrm{~g}(.2 \%)$ & $\begin{array}{l}\text { equal parts plant debris, quartz (mostly subrounded), and } \\
\text { angular clay lumps; lesser shell }\end{array}$ \\
\hline COARSE & $\# 35(.5 \mathrm{~mm})$ & $.36 \mathrm{~g}(.4 \%)$ & $\begin{array}{l}\text { equal parts plant debris and angular clay lumps; lesser } \\
\text { quartz (subrounded to subangular); occasional shell; rare } \\
\text { ferric concretions }\end{array}$ \\
\hline MEDIUM & $\# 60(.25 \mathrm{~mm})$ & $1.15 \mathrm{~g}(1.2 \%)$ & $\begin{array}{l}\text { equal parts quartz (subrounded to subangular) and plant } \\
\text { debris; slightly lesser angular clay lumps; occasional shell; } \\
\text { rare ferric concretions }\end{array}$ \\
\hline FINE & $\# 120$ (.125 mm) & $5.09 \mathrm{~g}(5.1 \%)$ & $\begin{array}{l}\text { mostly quartz (subangular to subrounded); slightly lesser } \\
\text { plant debris; lesser sponge spicules }\end{array}$ \\
\hline VERY FINE & $\# 170(.09 \mathrm{~mm})$ & $2.43 \mathrm{~g}(1.3 \%)$ & $\begin{array}{l}\text { more sponge spicules than quartz (mostly subangular); lesser } \\
\text { plant debris }\end{array}$ \\
\hline SILT & \#325 (.045 mm) & $1.51 \mathrm{~g}(1.5 \%)$ & $\begin{array}{l}\text { equal parts sponge spicules and quartz; lesser plant debris; } \\
\text { cottony texture }\end{array}$ \\
\hline SILT-CLAY & fine fraction $(<.045 \mathrm{~mm})$ & $89.00 \mathrm{~g}(89.1 \%)$ & mostly clay with some sponge spicules and silty quartz \\
\hline
\end{tabular}

Note: Adapted from Cordell and Koski 2003:118 (Table 3).

just exceeds, the suspected maximum firing temperature of much of the pottery that is analyzed at FLMNH-CTL. Half of the $600^{\circ} \mathrm{C}$ briquette is sent off for thin sectioning, ${ }^{10}$ and the other half is retained for curation. We currently have thin sections for about 85 percent of our curated clay samples and plan to have thin sections made of our entire collection as time and funding permit. We also now have comparative petrographic data (including point counts) for 162 of 304 thin-sectioned samples, assembled from some 18 different projects, many of which have been cited in this article. A portion of the $800^{\circ} \mathrm{C}$ briquette is reserved for Neutron Activation Analysis (NAA). We currently have NAA data for 150 samples, nearly all of which are from clays currently curated at the museum (Wallis et al. 2015). A few clay samples have been entirely consumed by NAA and/or petrographic thin sections. In future initiatives, we intend to analyze the fine fractions of sieved samples by X-Ray Diffraction (XRD) for clay mineral identification.

\section{Curation}

Leftover test bars, the set of fired briquettes, and sieved sediments are boxed together for curation (Figure 13) and labeled with our FLMNH accession number and clay sample number. Semi-rectangular polyethylene containers with lids are used for storing processed components of the sample clays. Gladware Soup \& Salad ${ }^{\mathrm{TM}}$ containers, or a generic equivalent (Appendix), are the perfect size. Any leftover clay is generally discarded. The excess of a few samples have been retained for experiments involving differing tempers or removal of excess 


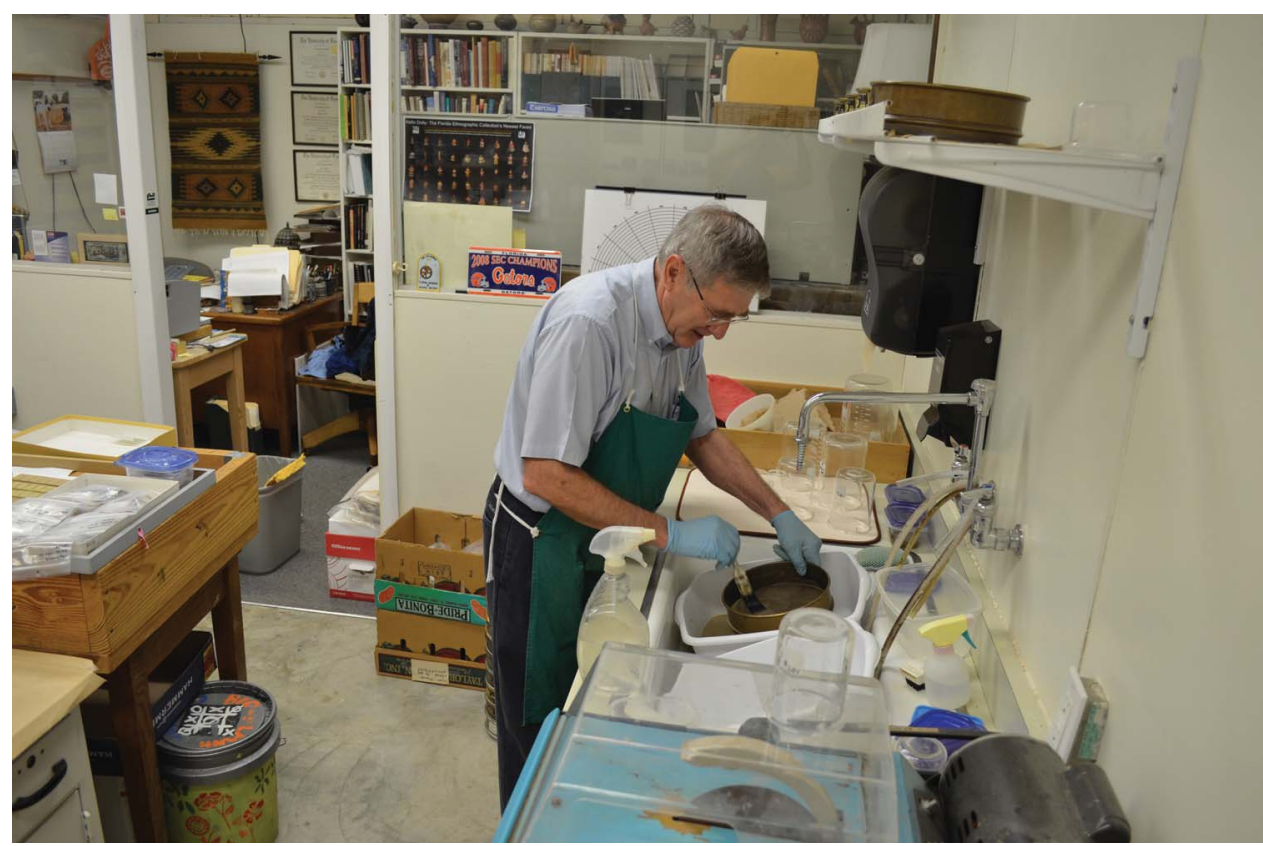

FIGURE 9. Dr. Gerald (Jerry) Kidder, wet sieving a clay sample.

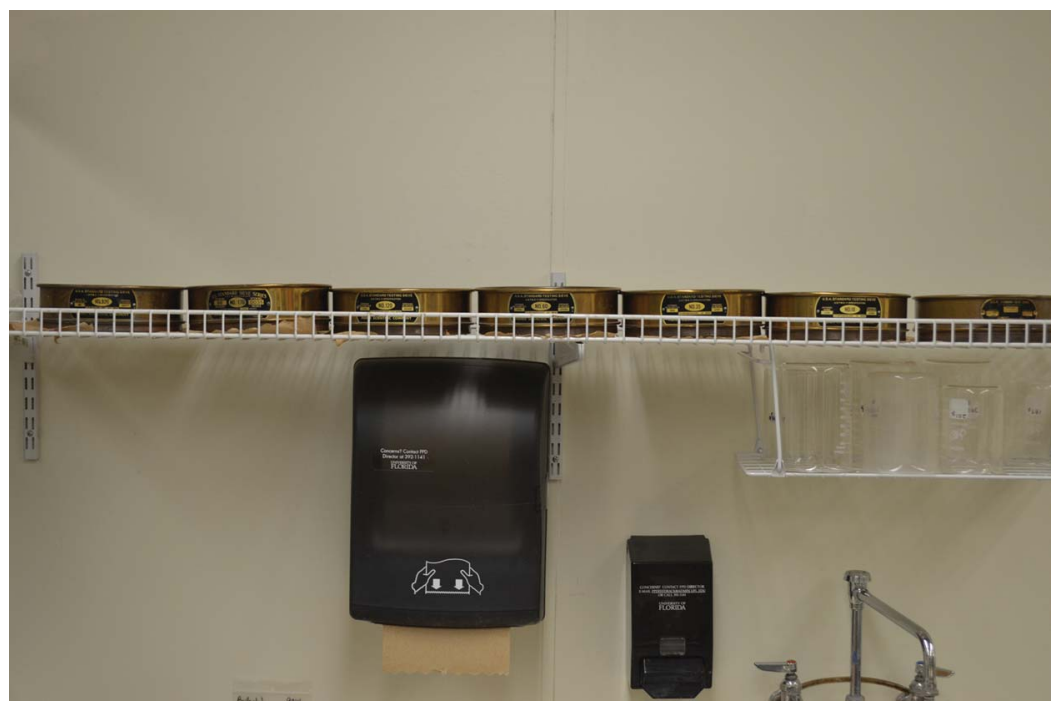

FIGURE 10. Sieved sediments air drying in the lab.

aplastics (e.g., Lollis et al. 2015), but space limitations prohibit routine curation of additional sample leftovers.

\section{COMPARATIVE CLAY SAMPLES IN ARCHAEOLOGICAL RESEARCH: POTENTIALS AND LIMITATIONS}

A primary use of the comparative samples is for provenance research. In order to correlate variation in pottery composition with the spatial distribution of resources, raw materials must be sampled (e.g., Arnold et al. 2000; Hein et al. 2004; Masucci and
Macfarlane 1997; Ruby and Shriner 2005). Countless studies of pottery provenance have proceeded without comparative data from sampled clays, but limited or no sampling of clayey sediments inevitably reduces the confidence of provenance assignments and the range of questions that can be investigated (Neff et al. 1992). Collection of clays proximate to archaeological sites under investigation is fairly common, and this is the source of most FLMNH-CTL accessions. Although intensive clay sampling around an archaeological site by itself can give a good approximation of a local signature, the geographic origins of compositional outliers in a pottery assemblage will remain highly speculative. In a region like Florida, where pottery was frequently transported hundreds of kilometers (e.g., Ashley et al. 2015; 


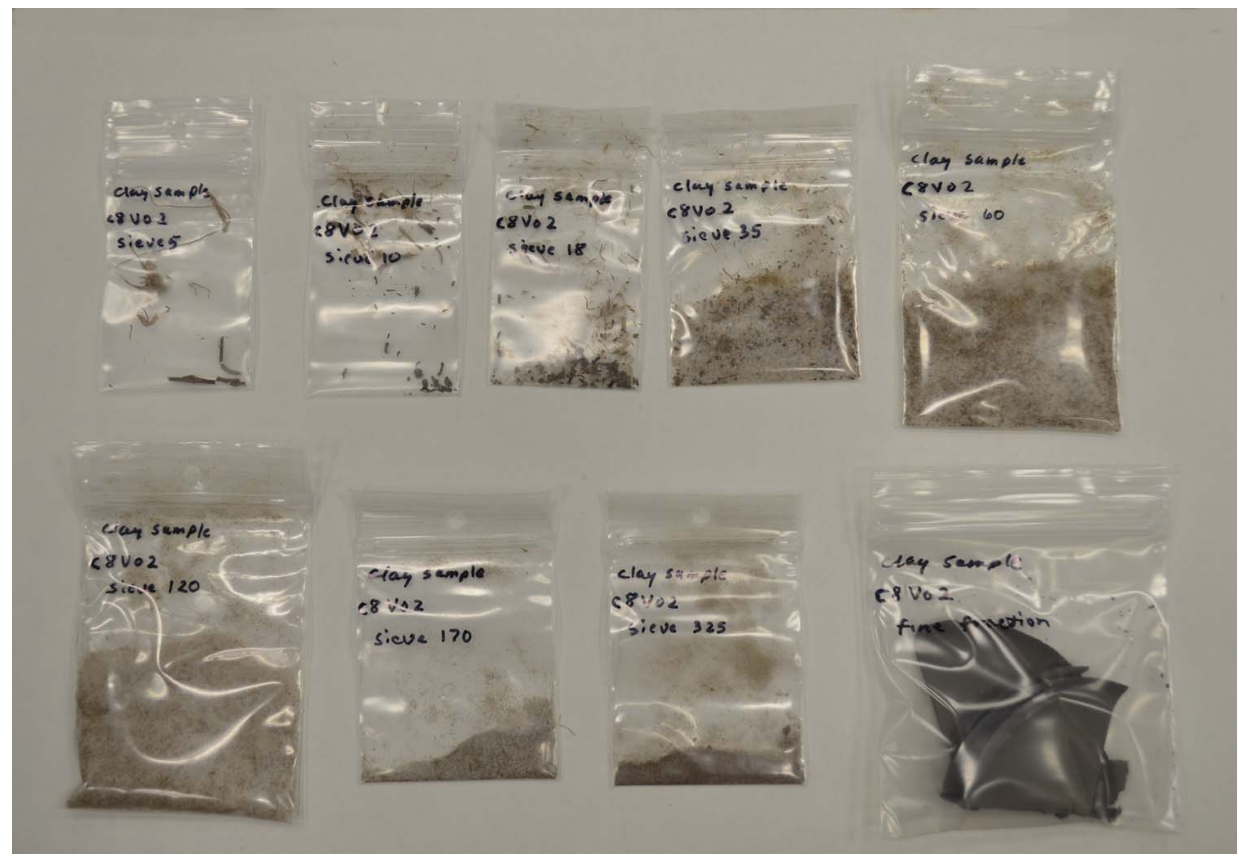

FIGURE 11. Sieved sediments bagged and labeled for curation.

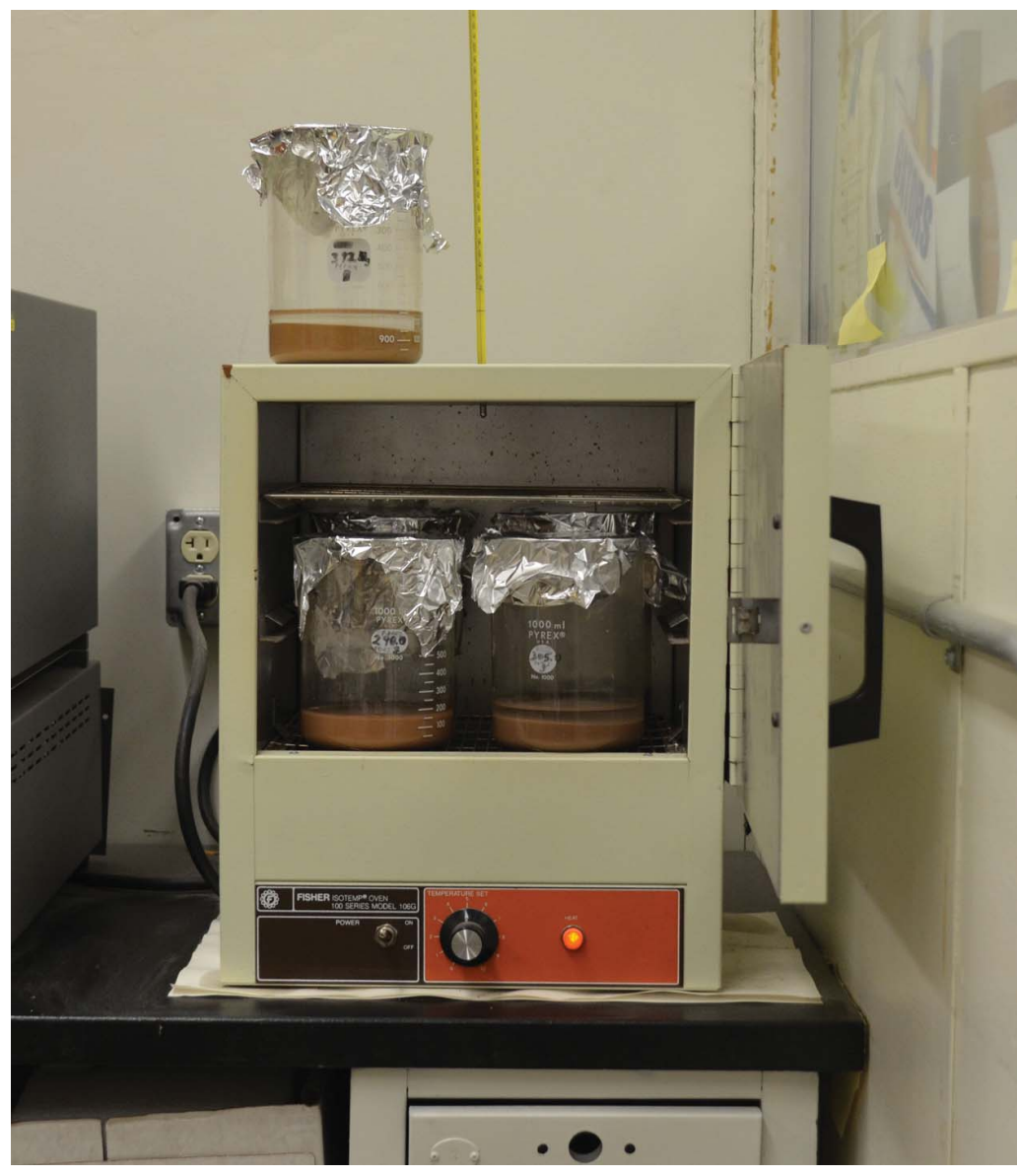

FIGURE 12. Beakers of fine fractions in drying oven (another sample, waiting for space in the oven, is sitting on top, getting a head start on the drying process). 


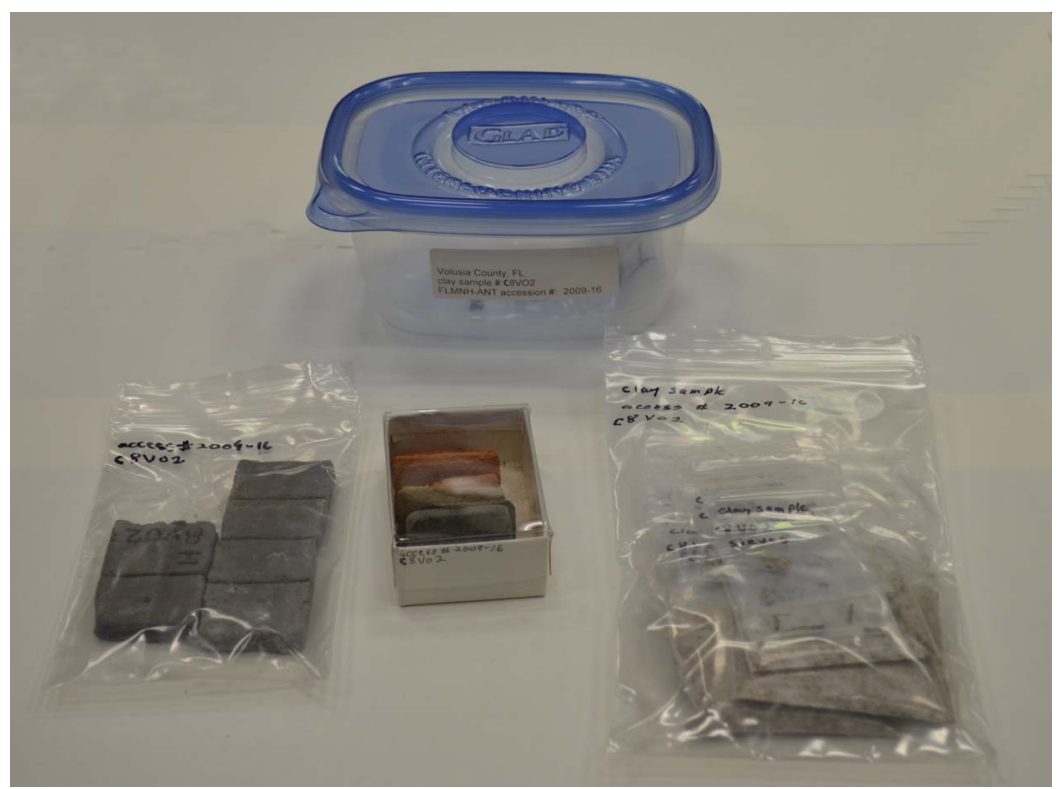

FIGURE 13. Processed sample clay ready for curation: (top) storage container, (bottom, left to right) leftover test bar, boxed fired briquettes, and bagged sieved sediments.

Gilmore 2016; Pluckhahn and Cordell 2011; Wallis 2011; Wallis and Cordell 2013; Wallis et al. 2016), a much broader sample is essential.

In Florida, we have found that clays exhibit broad geographic patterns in mineral inclusions and bulk chemistry that are useful markers for pottery provenance studies (Wallis et al. 2015). More than a dozen elements measured by NAA and mineral inclusions such as muscovite, calcareous matrix, phosphatic nodules, and siliceous microfossils observed in petrographic thin section show patterned distributions. These data are used to define compositional regions-geographic zones with clays that can be reliably distinguished from other zones. These compositional regions range from $50 \mathrm{~km}$ to more than $400 \mathrm{~km}$ in maximum dimension, thus dictating the scale at which "nonlocal" and "local" archaeological pottery can be differentiated. In other words, pottery transported less than $50 \mathrm{~km}$ in Florida is, in all cases, below the threshold of resolution for distinguishing it from vessels made at the site of archaeological excavation. In certain directions of transport, a vessel carried $400 \mathrm{~km}$ could look "local" in terms of its composition.

Another common use of clay samples has been in experimental studies. Although commercial clays offer the ability to conduct standardized experiments concerning performance characteristics (e.g., Schiffer and Skibo 1987), native clays are also useful for understanding the range of challenges faced by past potters in a specific region. For example, astoundingly few clay samples among the hundreds now curated at FLMNH-CTL approximate the extremely fine texture of St. Johns series pottery, ubiquitous across much of the state (Goggin 1952). Even processing the clays by pounding, sieving, and levigating has failed to replicate the texture of St. Johns pastes (Lollis et al. 2015). This incongruity between clays and St. Johns pottery indicates that we have yet to discover either the particular clay sources used or the techniques by which they were processed. We have also noted, in general, that many samples have excessive aplastics compared to the pottery, such that some excess would need to be removed to approximate suitable resources if comparable finer resources were not available.

The use of comparative clays is not without its problems. It would be difficult to determine whether clays had been mixed for pottery manufacture, for example, or processed to remove excess aplastics. For purposes of provenance research, sampling density is rarely completely adequate. Outliers within compositional regions tend to indicate that the entire range of compositional diversity is not well represented everywhere. As clays can vary compositionally even within a single deposit (Rice 2015:346-347), more sampling would strengthen our modeling of the ceramic landscape. Another, and related, challenge stems from the use of legacy data, that is, samples and records made at various times in the past and using a variety of protocols. Many samples are associated with very precise geographic coordinates and descriptions of the environmental setting while some others are merely associated with a dot on a USGS quad map. Likewise, a minimum sample size is not always present, and therefore not all data can be collected for every sample.

\section{SUMMARY/CONCLUSIONS}

The FLMNH-CTL curates pottery type collections and pottery thin sections and also an extensive collection of comparative clay samples, as well as thin sections of processed, fired samples. The SOP for processing and analysis of clay samples has been outlined. Curation and analysis of comparative clay samples at FLMNH-CTL spans nearly 40 years and myriad individual projects. Our comparative clay collection and data represent a valuable resource for ongoing and future lab endeavors and are available for other researchers focusing on Florida and adjacent regions. 
Our collection of processed samples and thin sections are curated in perpetuity.

\section{Acknowledgments}

We dedicate this article to mentor, friend, and colleague Pru Rice, with fondness and respect. Her close association with FLMNH colleagues (especially the late William R. Maples and Jerald T. Milanich) allowed FLMNH-CTL to actually "happen" and to endure after her departure from UF in 1991. The article benefited from Pru's thoughtful feedback. We also thank four anonymous reviewers for their most helpful consideration. Grants from the National Science Foundation (BCS-1356961 and BCS-1111397) and Wenner-Gren Foundation (Post-Ph.D. Research Grant 8337) provided funding for our ongoing projects. No permits were required for this research.

\section{Data Availability Statement}

Curated clays and thin sections are available at the Florida Museum of Natural History Ceramic Technology Laboratory for in-house study or for short-term loan to researchers at other institutions. Excel lists of curated clays and thin sections will soon be available on our website.

\section{Supplementary Material}

To view supplementary material for this article (the Appendix), please visit http://doi.org/10.1017/aap.2016.6.

\section{REFERENCES CITED}

Arnold, Dean E

1975 Ceramic Ecology of the Ayacucho Basin, Peru: Implications for Prehistory. Current Anthropology 16:183-205.

1985 Ceramic Theory and Culture Process. Cambridge University Press, Cambridge.

Arnold, Dean E., Hector Neff, and Michael D. Glascock

2000 Testing Assumptions of Neutron Activation Analysis: Communities, Workshops, and Paste Preparation in Yucatán, Mexico. Archaeometry 42:301-316.

Ashley, Keith H., Neill J. Wallis, and Michael D. Glascock

2015 Forager Interactions on the Edge of the Early Mississippian World: Neutron Activation Analysis of Ocmulgee and St. Johns Pottery. American Antiquity 80:290-311.

Beck, Margaret E.

2006 Linking Finished Ceramics to Raw Materials: Oxidized Color Groups for Lowland Desert Clays. Kiva: The Journal of Southwestern Anthropology and History 72(1):93-118.

Bishop, Ronald L., and M. James Blackman

2002 Instrumental Neutron Activation Analysis of Archaeological Ceramics: Scale and Interpretation. Accounts of Chemical Research 35(8):603-610.

Borremans, Nina Thanz, and Graig D. Shaak

1986 Preliminary Report on Investigation of Sponge Spicules in Florida "Chalky" Paste Pottery. Ceramic Notes 3:125-131.

Cordell, Ann S

1984 Ceramic Technology at a Weeden Island Period Archaeological Site in North Florida. Ceramic Notes No. 2. Occasional Publications of the Ceramic Technological Laboratory, Florida State Museum.

1992 Technological Investigation of Pottery Variability in Southwest Florida. In Culture and Environment in the Domain of the Calusa, edited by William H. Marquardt, pp. 105-189. Monograph No. 1 of the Institute of Archaeology and Paleoenvironmental Studies, University of Florida, Gainesville.
2004 Paste Variability and Possible Manufacturing Origins of Fiber-tempered Pottery from Florida. In Early Pottery: Technology, Function, Style, and Interaction in the Lower Southeast, edited by Rebecca Saunders and Christopher T. Hayes, pp. 63-104. University of Alabama Press, Tuscaloosa.

2007 Petrographic Evaluation of Belle Glade and Sandy St. Johns Pastes. Florida Anthropologist 60(2-3):117-126.

Cordell, Ann S., and Steven H. Koski

2003 Analysis of a Spiculate Clay from Lake Monroe, Volusia County, Florida. Florida Anthropologist 56(2):113-124.

Espenshade, Christopher T.

1985 Ceramic Ecology and Aboriginal Household Pottery Production at the Gauthier Site, Florida. Unpublished Master's thesis, Department of Anthropology, University of Florida, Gainesville.

Gilmore, Zackary I.

2016 Gathering at Silver Glen: Community and History in Late Archaic Florida. University Press of Florida, Gainesville.

Goggin, John M.

1952 Space and Time Perspective in Northern St. Johns Archeology, Florida. Yale University Publications in Anthropology, Number 47

Hein, Anno, Peter M. Day, Miguel Angel Cau Ontiveros, and Vassilis Kilikoglou 2004 Red Clays from Central and Eastern Crete: Geochemical and Mineralogical Properties in View of Provenance Studies on Ancient Ceramics. Applied Clay Science 24(3-4):245-255.

Jorge, Ana, M. Isabel Dias, and Peter M. Day

2013 Plain Pottery and Social Landscapes: Reinterpreting the Significance of Ceramic Provenance in the Neolithic. Archaeometry 55(5):825-51.

Kelly, Sophia E., Christopher N. Watkins, and David R. Abbott

2011 Revisiting the Exploitable Threshold Model: 14th Century Resource Procurement and Landscape Dynamics on Perry Mesa, Arizona. Journal of Field Archaeology 36(4):322-336.

Kolb, Charles C., and Louana M. Lackey (editors)

1988 A Pot For All Reasons: Ceramic Ecology Revisited. Laboratory of Anthropology, Temple University, Philadelphia, Pennsylvania.

Lollis, Charly, Neill J. Wallis, and Ann S. Cordell

2015 Was St. Johns Pottery Made with Swamp Muck as Temper? An Experimental Assessment. Florida Anthropologist 68(3-4):97-112.

Masucci, Maria, and Allison Macfarlane

1997 An Application of geological Survey and Ceramic Petrology to Provenance Studies of Guangala Phase Ceramics of Ancient Ecuador. Geoarchaeology 12(7):765-793.

Matson, Frederick R

1965 Ceramic Ecology: An Approach to the Study of the Early Cultures of the Near East, In Ceramics and Man, edited by Frederick R. Matson, pp. 202-217. Aldine, Chicago, Illinois.

Michelaki, Kostalena, Gregory V. Braun, and Ronald G.V. Hancock

2015 Local Clay Sources as Histories of Human-Landscape Interactions: A Ceramic Taskscape Perspective. Journal of Archaeological Method and Theory 22(3):783-827.

Mitchem, Jeffery M.

1986 Analysis of Ceramics from the South Prong I site (8-Hi-418). Ceramic Notes No. 3, pp. 81-109. Occasional Publications of the Ceramic Technological Laboratory, Florida State Museum.

Neff, Hector, and Frederick J. Bove

1999 Mapping Ceramic Compositional Variation and Prehistoric Interaction in Pacific Coastal Guatemala. Journal of Archaeological Science 26:1037-1051.

Neff, Hector, Frederick J. Bove, Brenda L. Lou P., and Michael F. Piechowski 1992 Ceramic Raw Materials Survey in Pacific Coastal Guatemala. In Chemical Characterization of Ceramic Pastes in Archaeology, edited by Hector Neff, pp. 59-84. Prehistory Press, Madison, Wisconsin.

Pluckhahn, Thomas J., and Ann S. Cordell

2011 Paste Characterization of Weeden Island Pottery from Kolomoki and Its Implications for Specialized Production. Southeastern Archaeology 30(2):288-310.

Quinn, Patrick Sean

2013 Ceramic Petrography: The Interpretation of Archaeological Pottery \& Related Artefacts in Thin Section. Archaeopress, Oxford. 
Rice, Prudence M.

1987 Pottery Analysis: A Sourcebook. University of Chicago Press, Chicago, Illinois.

2015 Pottery Analysis: A Sourcebook. 2d ed. University of Chicago Press, Chicago, Illinois.

Ruby, Brett J., and Christine M. Shriner

2005 Ceramic Vessel Compositions and Styles as Evidence of the Local and Nonlocal Social Affiliations of Ritual Participants at the Mann Site, Indiana. In Gathering Hopewell, edited by Christopher Carr and D. Troy Case, pp. 553-572. Kluwer Academic/Plenum Publishers, New York

Rye, Owen S.

1981 Pottery Technology: Principles and Reconstruction. Manuals on Archaeology 4. Taraxacum, Washington, D.C.

Saffer, Marion E.

1979 Aboriginal Clay Resource Utilization on the Georgia Coast. Unpublished Master's thesis, Department of Anthropology, University of Florida, Gainesville.

Schiffer, Michael B., and James M. Skibo

1987 Theory and Experiment in the Study of Technological Change. Current Anthropology 28:595-622.

Shepard, Anna O.

1976 Ceramics for the Archaeologist. Carnegie Institution of Washington Publication, Vol. 609. Washington, D.C.

Sillar, Bill

2000 Dung by Preference: The Choice of Fuel as an Example of How Andean Pottery Production Is Embedded within Wider Technical, Social, and Economic Practices. Archaeometry 42(1):4360.

Stark, Miriam T., Ronald L. Bishop, and E. Miksa

2000 Ceramic Technology and Social Boundaries: Cultural Practices in Kalinga Clay Selection and Use. Journal of Archaeological Method and Theory 7(4):295-331.

United States Department of Agriculture (USDA)

1951 Soil Survey Manual. USDA Handbook 18. U.S. Government Printing Office.

Wallis, Neill J.

2011 The Swift Creek Gift: Vessel Exchange on the Atlantic Coast. University of Alabama Press, Tuscaloosa.

Wallis, Neill J., and Ann S. Cordell

2013 Petrographic Analysis of Pottery and Clay Samples from the Georgia Bight: Evidence of Regional Social Interactions. In Life Among the Tides: Recent Archaeology on the Georgia Bight, edited by Victor D. Thomson and David Hurst Thomas, pp. 119-142. American Museum of Natural History Anthropological Papers No. 98

Wallis, Neill J., Ann S. Cordell, Kathleen A. Deagan, and Michael J. Sullivan

2014 Inter-ethnic Social Interactions in 16th Century La Florida: Sourcing Pottery Using Siliceous Microfossils. Journal of Archaeological Science 43:127-140.

Wallis, Neill J., Thomas J. Pluckhahn, and Michael D. Glascock

2016 Sourcing Interaction Networks of the American Southeast: NAA of Swift Creek Complicated Stamped Pottery. American Antiquity 81:717-736.

Wallis, Neill J., Zackary I. Gilmore, Ann S. Cordell, Thomas J. Pluckhahn, Keith H. Ashley, and Michael D. Glascock

2015 The Ceramic Ecology of Florida: Compositional Baselines for Pottery
Provenance Studies. Science and Technology of Archaeological Research 1(2):29-48.

Wentworth, Chester K

1922 A Scale of Grade and Class Terms for Clastic Sediments. Journal of Geology 30:377-392.

\section{NOTES}

1. Rice was then a University of Florida professor of anthropology (now Distinguished Professor Emerita at Southern Illinois University Carbondale).

2. More than 400 are from nearly 90 Florida sites. The others are from the southeastern United States $(n=180)$, Michigan $(n=6)$, the Caribbean $(n=$ 176), Central America $(n=42)$, and Spain $(n=3)$. FLMNH-CTL is becoming a premier repository for ceramic resource data in Florida and the lower southeastern United States. We invite researchers with thin sections to consider FLMNH-CTL for permanent curation at no cost.

3. As of this writing, 216 are from Florida, 52 from Georgia, 17 from elsewhere in the southeastern United States, and the rest from Puerto Rico, Dominica, and Ecuador.

4. Dr. Gerald (Jerry) Kidder (Figure 9) joined the lab in 2013. His professional background led to improved methods of processing.

5. Our SOP is tailored to balance our goal of characterizing the physical properties of the raw clays with expediting the processing of our backlog. Thus, certain processing steps and physical properties that were included in Rice's seminar were eliminated in our SOP (including "aging" the clay mass and routine experimentation with added tempers, Mohs Hardness, porosity, and firing weight loss [see Rice 2015 for explanations]). However, curated samples are available for other such analyses.

6. Vikane (sulfuryl fluoride- $\mathrm{SO}_{2} \mathrm{~F}_{2}$ ) is the fumigant used by UF. It is the accepted fumigant for museum specimens for being nonreactive. However, FLMNH is considering a cost saving switch to freezing and/or anoxic methods.

7. Uncrushed clay lumps that pass through the sieve seem to, in most cases, disintegrate when water is added and the clay mass is worked. Some lumps survive this process but only in the finest samples, as observed in thin section.

8. Our electric furnace is somewhat programmable and automated (see Appendix) in terms of setting and increasing firing temperatures. We also have a portable furnace with manual settings that we take outside for firing extremely organic samples (to avoid setting off building smoke alarms and/or to avoid complaints of a strong and/or unpleasant burning odor).

9. Wentworth Scale is reproduced in Rice (2015:42) and Shepard (1976:118)

10. We use Spectrum Petrographics for thin sectioning (http://www.petrography.com/).

\section{AUTHORS INFORMATION}

Ann S. Cordell and Neill J. Wallis $\square$ Florida Museum of Natural History, Dickinson Hall, University of Florida, 1659 Museum Road, Gainesville, FL 32611 (cordell@flmnh.ufl.edu; nwallis@flmnh.ufl.edu)

Gerald Kidder 3429 NW 27th Place, Gainesville, FL 32605; University of Florida (retired) (gkidder@cox.net) 